\title{
WORKING MOTHER AND FAMILY ECONOMY RESILIENCE IN THE COVID-19 ERA: EVIDENCE FROM INDONESIA
}

\author{
Siti Nur Azizah ${ }^{{ }^{*}}$, Annisa Nur Salam² \\ ${ }^{1}$ Faculty of Islamic Economics and Business, Sunan Kalijaga State Islamic University, \\ Yogyakarta 55281, Indonesia \\ ${ }^{2}$ Faculty of Islamic Economics and Business, Sunan Gunung Djati State Islamic University, \\ Bandung 40614, Indonesia
}

*E-mail: azizyziandra@gmail.com

\begin{abstract}
Covid-19 pandemic, which occurred in early 2020, has resulted in more than 50 percent of households experiencing financial difficulties, especially those who rely on personal businesses. This study aims to analyze the effect of working mothers on family economic resilience during the Covid-19 pandemic. This study obtained the primary data by distributing questionnaires to 173 respondents using the purposive sampling technique. The respondents' characteristics are working mothers who work for at least 2 hours per day, are aged 17-70 years, have an income of at least 250 thousand rupiahs per month, are married, and already have children. The approach used is quantitative with Ordinary Least Square (OLS) as the data analysis method. The dependent variable is family economic resilience, and the independent variable is female workers. The results showed that working women could support and contribute to their households in helping meet the daily needs of their families. Thus, working mothers have a positive effect on household economic resilience during the Covid-19 pandemic. For this reason, during the Covid-19 period, a wife's role is needed to contribute to the family economy so that the family's economic resilience remains stable. Furthermore, this research revealed the importance of the government's roles and stakeholders to provide facilities such as working capital for women, availability of employment opportunities for women, and work regulations that support women in balancing their dual roles.
\end{abstract}

Keywords: Covid-19 pandemic, family economic resilience, ordinary least square, working mother

\section{Wanita Pekerja dan Ketahanan Ekonomi Keluarga pada Era Covid-19: Fakta di Indonesia}

\begin{abstract}
Abstrak
Covid-19 yang terjadi pada awal 2020 menyebabkan lebih dari 50 persen rumah tangga mengalami kesulitan keuangan terutama yang mengandalkan usaha pribadi. Penelitian ini bertujuan untuk menganalisis pengaruh ibu pekerja terhadap ketahanan ekonomi keluarga selama pandemi Covid-19. Penelitian ini menggunakan data primer dengan membagikan kuesioner kepada 173 responden menggunakan teknik purposive sampling. Karakteristik responden yang digunakan merupakan ibu yang bekerja minimal 2 jam per hari, berusia 17-70 tahun, memiliki penghasilan minimal 250 ribu per bulan, memiliki status menikah dan sudah memiliki anak. Adapun pendekatan yang digunakan adalah kuantitatif dengan metode analisis data yang digunakan adalah Ordinary Least Square (OLS) dengan variabel dependennya adalah ketahanan ekonomi keluarga dan variabel independennya adalah wanita pekerja. Hasil penelitian menunjukkan bahwa perempuan yang bekerja menjadi kontribusi atau penunjang rumah tangga dalam membantu memenuhi kebutuhan sehari-hari keluarganya. Dengan demikian, wanita yang bekerja berpengaruh positif terhadap ketahanan ekonomi rumah tangga selama pandemi Covid-19. Untuk itu, di masa Covid-19 diperlukan adanya peran istri untuk berkontribusi dalam ekonomi keluarga sehingga ketahanan ekonomi keluarga tetap stabil. Penelitian ini menegaskan pentingnya peran dan dukungan pemerintah dan pemangku kepentingan terkait untuk memberikan kemudahan seperti modal kerja bagi perempuan, tersedianya kesempatan kerja bagi perempuan, dan peraturan kerja yang mendukung perempuan dalam menyeimbangkan peran gandanya.
\end{abstract}

Kata kunci: ketahanan ekonomi keluarga, ordinary least square, pandemi Covid-19, wanita pekerja

\section{INTRODUCTION}

Various countries in the world have experienced instability in the economic sector due to the crisis caused by the Covid-19
Pandemic (Muykim, 2020), including Indonesia (ADB, 2020). Economic growth slowed down in the second quarter of 2020 and contracted to minus 5.32 percent year-on-year (Solihatin, 2017). This is due to a higher deficit, slower 
growth, depreciation of the rupiah (Solihatin, 2017), interest rate shocks, and more loans to finance the stimulus package (UNCTAD, 2020). The household consumption sector experiences the most significant contraction (Kansiime et al., 2021). A decrease in economic activity at the household level is caused by the decline of household income (Baker, Farrokhnia, Meyer, Pagel \& Yannelis, 2020), which further triggers a decrease in consumption levels and a decline in people's purchasing power (Yue, Korkmaz \& Zhou, 2020). As the central pillar of the economy, household consumption slowed down significantly, decreasing from 3.22 percent to 1.60 percent. It subsequently impacts the performance of industry and Micro, Small, and Medium Enterprises (MSME) (Saleh \& Ndubisi, 2014). It further affects gross domestic product growth or GDP (Bagchi-Sen, 2010), which declines from 2.3 percent to -0.4 percent. This figure is far below the initial assumption of the 2020 state budget (APBN), which reached 5.3 percent. As a result, the government predicts economic growth will fall to 2.3 percent. Even in a worse scenario, it could reach -0.4 percent. (Warta Ekonomi, 2020).

A survey conducted by the LIPI (2020) shows that the Covid-19 Pandemic has caused a downturn in household economic sustainability. More than 50 percent of households experience financial difficulties, especially those which rely on the business. To be precise, the data shows that only 48 percent of household-based businesses are still surviving. Meanwhile, households that rely on jobs experience a decrease of around 22 percent. This is due to the government policy to stop the spread of Covid-19, namely Large-Scale Social Restrictions (PSBB), to limit the mobility of people in an area. The PSBB policy causes economic activity. This impacts the company's economy and the family economy, such as a decrease in income, cuts in wages, a decrease in profits, and the limited space for consumption (Susilawati, Falefi, \& Purwoko, 2020). Some households even experienced sudden layoffs (Suryahadi, Al Izzati, \& Suryadarma, 2020). Therefore, business-based and work-based households take advantage of savings, assets, and/or loans from relatives to fulfill their needs (Supriatna, 2020). This condition ultimately destabilizes household economic resilience.

Several studies related to the impact of Covid19 on the household economy show the poor household is more severely affected than the middle and wealthy households (Hertz, Mattes \& Shook, 2020). This kind of family's impact is just slightly different from that felt by a family with husband and wife working together (Arsal, Basri, \& Tono, 2017). Working mothers significantly impact family economic resilience, and their contribution has played an integral part in national development (Sunarti, Rizkillah, Hakim, Zakiya \& Damayanti, 2021). Likewise, in the economic sector, women equally share family income (Botezat \& Pfeiffer, 2014). Therefore, mothers have a role in strengthening on family economic resilience.

Based on the Central Bureau of Statistics (BPS, 2019), 55.50 percent of married women aged 17 to 70 decide to work in the formal sector in Indonesia. This figure increases by 0.06 percent compared to the same period in 2018 and 5.50 percent compared to the same period in 2013. This increase was due to the changes in housewives' orientation in which they have started to take part in meeting the economic needs of their family (Duflo, 2012); achieving family welfare (Huebener, Waights, Spiess, Siegel, \& Wagner, 2020); and providing children's health costs (Karpman, Gonzalez, \& Kenney, 2020; Araújo, Veloso, Souza, Azevedo, \& Tarro, 2020); and children's education (Hoque, Khanam, \& Nobi, 2017; Dhingra \& Keswani, 2018). Mothers have also started to consider the advantages of having a career, including social stimulation (Stephiana \& Wisana, 2019), achieving family economic stabilization (Wulandari, Putri, \& Yulia, 2019), and maintaining their mental health (Hosna et al., 2020). Having additional income will also help increase nutrition for their children (Fallah, Hattawy, Hashhas, \& Saedah, 2019., Fallah, Bergolo, Hashhash, Hattawy, \& Saadeh, 2019).

This orientation is inversely proportional to the original motive of working mothers to take advantage of education and increasingly limited job opportunities (Melis, 2017), especially in pandemic conditions that cause increasingly uncertain economic diseases (Baker, Farrokhnia, Meyer, Pagel \& Yannelis, 2020). Therefore, it is clear that women can build a safety value or support for their household to fulfill their daily needs by having a job (Aziz \& Sholikha, 2017).

This research was conducted because of the different reality between the data described and previous research. People should have had a high resilience in facing difficult situations caused by the pandemic. However, the fact shows the opposite, and the majority of business-based households and job-based households experience financial difficulties 
during the pandemic. The most severe impact is especially felt by business households, with around 87.3 percent and two-third of working families, on the other hand, are also affected. These two households mainly experience financial difficulties with an income class of fewer than 3 million rupiahs per month. However, households that rely on the job find it more challenging to finance consumption of food, namely by 52.9 percent, while the business household is relatively lower, namely 37.8 per cent (Sina, 2020)

This data and reality suggest that working households have a higher resilience than business families during the pandemic but have difficulty meeting their survival needs. This further necessitates the role of women in work to increase the economic resilience of the family, not only as an object but as a subject involved in strengthening the family economy for the realization of family balance, especially during a pandemic (Casmini, 2020). Women's participation does not only affect their families, but it is also extended to the lives of the surrounding community. And at the macro level, their participation can help increase economic stability (Dhingra \& Keswani, 2018).

It means that family is an important domain that plays an influential role for a country, and a country cannot have resilience if families cannot survive. Therefore, the present study focuses on examining the role of working mothers in family financial resilience during the Covid-19 Pandemic (Celik, Ozden, \& Dane, 2020).

Family resilience refers to a condition in which a family can provide adequate and sustainable income to fulfill their primary needs such as food, clean water, health services, educational opportunities, housing, time to participate in society, and social integration (Lei, Liu, \& Hill, 2017). It is also defined as the ability to survive and adapt to various conditions that are constantly changing. A resilient family has a positive attitude towards multiple challenges in life (Kring, 2017) so that they have tolerance for prolonged uncertainty and can adapt and endure adversity (Simon et al., 2013). Furthermore, they will continue to adapt positively to internal and external dangers and threats (Martin et al., 2020). Consequently, they will be able to utilize their potential to face challenges in life, including the ability to restore family functions to normal in the face of challenges and crises (Bhana \& Bachoo, 2011).

A family with high resilience is characterized by the ability to go through a period of difficulty to overcome their traumas with good self-righting
(Masten, 2018). In addition, they can manage emotions and stress (Masten, 2018). Stress management is part of an individual's existence, which will positively impact health so that family functions can run well (Bonanno, 2008). A family that has a high spirit of altruism among family members can maintain good family relationships. They can also create a positive atmosphere, protect dignity, and have high harmony (Verma \& Negi, 2020).

A family's resilience can also be seen from several aspects, namely the aspects of health, economy, harmony, education, and social and cultural aspects (Faccio et al., 2018). Families have the resilience and high physical, material and mental, and spiritual abilities so they can live independently (Donnelly et al., 2016). They also have high harmony and always try to improve their physical and mental well-being (Bhana \& Bachoo, 2011). Therefore, this family has two latent factors: physical resilience and social resilience (Afifi, Merrill, \& Davis, 2016; Sunarti, 2006)

Economic resilience is a component crucial to family strength. It also refers to the ability of families to quickly recover from adverse shocks and problems that have an impact on their financial imbalances (Bank for International Settlements, 2016). According to (BPS, 2016) the condition of a family's economic resilience can be seen from several factors: husband and wife steady income, at least to meet monthly needs. It is also indicated by the absence of debt and the availability of savings for children's schooling. Economically resilient families particularly do not have children who drop out of school, and they also have health insurances that cover all family members. Additionally, they can quickly fulfill their basic needs for food, shelter, and clothing. Thus, the economic resilience of a family can be described as the ability of a family to meet the family's various needs to live a comfortable and sustainable life (Lobo, 2008).

In their research, Simon et al. (2013) identified and created a PER (Path toward Economic Resilience) program in their research. Their research suggests that family economic resilience can be achieved through health security. Health is indeed an important indicator because a family who is unable to maintain the health of their family members and suffering from a critical illness will threaten and even erode the family finances (Dhingra \& Keswani, 2018). This will further cause poverty (Cross \& Emanuel, 2008) and affect their employment resulting in decreased income, increased 
spending, unemployment (Weinstein, 1996), minimal ownership of health insurance (Feinberg et al., 2011), and the decline in pension fund preparation (Dentinger \& Clarkberg, 2002). Generally, diseases are very detrimental. They harm the economy like the Covid-19 pandemic, resulting in economic shocks caused by a significant decrease in family income due to lockdowns even though part of the community gets substantial assistance such as food and communication (Celik et al., 2020).

Furthermore, families are considered to have good economic resilience if they can pay for children's education to complete the 12-year compulsory education and guarantee the family members to get an education (Yulianti, Denessen, \& Droop, 2019). On the other hand, the presence of family members who drop out of school is an indication of economic problems in the family, although the cause of dropping out of school is not always economic reasons (BPS, 2020; Ghazi, Ali, Shahzad, Shahzada, \& Nawaz, 2011; Muttaqin, Wittek, Heyse, \& Duijn 2017). Different from the research conducted by Munandar \& Suryatman (2019), it is said that socioeconomic status is not the only family factor affecting the dropout rate, but also the number of family members, number of siblings, and the educational background of the parents. In addition, the dropout rate is also influenced by parents' decisions that prefer children to work (Christian Dustmann and Arthur van soest, 2008). The dropout rate is categorized based on the level of education in which more than a third of students drop out during elementary school. In contrast, junior high school and vocational school dropouts are more than 20 percent. On the other hand, the high school dropouts are relatively low (Kemendikbud, 2020). This means that around 62.64 percent of Indonesian families have a fairly good level of economic resilience in education.

One of several previous studies that discussed household economic resilience was conducted by Shahreza and Lindiawatie (2020) with research on Family Economic Resilience in Depok during the Covid-19 pandemic. This research used qualitative methods and was limited to the Depok area. Another study was conducted by Setiawan et al. (2020), entitled The Existence of Female Workers (Wives) in the Informal Sector in Improving Family Welfare (Study of Abeli Village, Abeli District, Kendari City). The study used qualitative methods and was limited to the Kendari City area.
Our research complements previous research because none of them used a quantitative approach with statistical data processing. Therefore, this research tries to examine a similar theme with a different approach, using a quantitative approach with the Ordinary Least Square (OLS) method. Furthermore, this study aimed to analyze the effect of working mothers on family economic resilience during the Covid19 pandemic. Based on these objectives, the provisional conclusion of this study is that working mothers have a positive effect on family economic resilience. Therefore, the hypothesis used in this study is working mothers influence family economic resilience during the Covid-19 pandemic.

\section{METHOD}

To analyze the effect of the independent variable on the dependent variable, this study involved working mothers in Indonesia who worked for at least or more than 2 hours per day. The random sampling technique was used to select relevant respondents from the entire research population. Questionnaires were distributed online via Google Form to predetermined people. The pilot study was conducted from 03 January to 05 February 2021 , in which 50 respondents were involved. However, this number was reduced based on the validity and reliability test because of some invalid responses and unreliable questions. Once the questionnaire was revised, the researchers redistributed the questionnaire to some predetermined respondents through several WhatsApp (WA) groups on 10 February - 29 February 2021. The redistribution of the questionnaire through the WhatsApp group reached 196 respondents living across 32 provinces in Indonesia.

Researchers eliminated 23 respondents after considering the completeness of information from 196 respondents. Finally, it was determined that 173 respondents had met the totality of the data (Krejcie \& Morgan, 1970). The sample criteria are: 1) those who work in both formal and non-formal sectors, 2) full-time and part-time, and 3 ) with an age range of 1770 years. Working mothers are women (i) who work for more than two hours. The respondents represent working mothers across 32 provinces in Indonesia. The sociodemographic data were analyzed using descriptive analysis. Respondents were selected using a systematic random sampling method. One hundred seventy-three (173) respondents were selected for data analysis purposes and were deemed 
adequate representatives of the entire population (Sekaran, 2003).

The primary outcome of the effect of the independent variable on the dependent variable is proxied by indicators of household economic resilience in Indonesia, including monthly fixed family income, ownership of a house or place of residence, ability to pay for children's education, ownership of health insurance. Working mother variable as an independent variable is proxied by the mother's monthly income, which can help the family meet their economic needs

This research used the ordinary least square (OLS) method to see the effect of independent variables on the dependent variable (Ghozali, 2013). The steps used in measuring the model in this study include conducting a validity test, reliability test, classical assumption test, $F$ difference test, determination coefficient test (RSquare), and $\mathrm{T}$ difference test. Data analysis was performed using the Statistical Package for the Social Sciences (SPSS) software tool. Simple linear regression analysis was used to determine the effect of working mothers on household economic resilience during the Covid-19 Pandemic. Based on the description above, the multiple linear regression equation in this study can be written as follows:

$$
Y=\propto+\beta X+e
$$

where $Y$ is household economic resilience, $\propto$ is constant, $\beta$ is coefficient, $X$ is working mother, and $e$ is an error.

These variables are measured by various indicators using the Likert Scale. Likert scale is a scale to measure attitudes, opinions, and perceptions of someone regarding social phenomena. The alternative answers on the Likert scale include strongly agree (score 4), agree (score 3), disagree (score 2), and strongly disagree (score 1).

\section{RESULT}

\section{The Characteristics of Working Mother}

The data shows that respondents aged between 30-39 years occupied 56.1 percent of the total share-based on age. The religion of most respondents in this study is Islam, with a frequency of $(93.1 \%)$, while in terms of education, most respondents hold S1/bachelor degrees with a frequency of $(45.1 \%)$. This is because there is a relationship between education and the type of work. Mothers with an undergraduate education background or higher have a greater chance of getting a job than mothers who graduated only from high school and below. This is because they may be required to have a specific skill for a particular type of job. Based on the respondent's occupation in this study, it shows that most respondents' occupations are civil servants and police personnel with a frequency of 3.7 percent and 75.1 percent, respectively, belonging to the full-time and formal type of work. Furthermore, in this study, 42.8 percent of respondents had two children (Table 1).

Table 1 Characteristics of working mother

\begin{tabular}{|c|c|c|}
\hline Variable & Category & Percent \\
\hline \multirow[t]{5}{*}{ Age } & $18-29$ yo & 14.5 \\
\hline & $30-39$ yo & 56.1 \\
\hline & $40-49$ yo & 17.9 \\
\hline & $50-59$ yo & 9.8 \\
\hline & $60-69$ yo & 1.7 \\
\hline \multirow[t]{4}{*}{ Religion } & Islam & 93.1 \\
\hline & Christian & 2.9 \\
\hline & Catholic & 3.5 \\
\hline & Hinduism & 0.6 \\
\hline \multirow[t]{10}{*}{ Education } & Elementary & 0.6 \\
\hline & $\begin{array}{l}\text { Graduated from junior } \\
\text { high school/equivalent }\end{array}$ & 4.0 \\
\hline & $\begin{array}{l}\text { Graduated from Senior } \\
\text { high school/equivalent }\end{array}$ & 11.0 \\
\hline & Diploma I & 1.7 \\
\hline & Diploma II & 0.6 \\
\hline & Diploma III & 6.9 \\
\hline & Bachelor (S1) & 45.1 \\
\hline & Master's (S2) & 25.4 \\
\hline & Doctoral (S3) & 4.0 \\
\hline & $\begin{array}{l}\text { Drop out from } 12 \text {-year } \\
\text { compulsory education }\end{array}$ & 0.6 \\
\hline \multirow[t]{6}{*}{ Occupation } & Civil Servant, Police & 34.7 \\
\hline & General employees & 27.2 \\
\hline & Self-employed & 8.7 \\
\hline & Traders & 8.1 \\
\hline & Teacher & 15.6 \\
\hline & Domestic helpers & 5.8 \\
\hline \multirow{2}{*}{$\begin{array}{l}\text { Type of } \\
\text { occupation }\end{array}$} & Part-time & 24.9 \\
\hline & Full time & 75.1 \\
\hline \multirow{4}{*}{$\begin{array}{l}\text { Duration of } \\
\text { work }\end{array}$} & $<1$ year & 2.9 \\
\hline & 1-3 year & 17.3 \\
\hline & 4-6 year & 19.1 \\
\hline & $>6$ year & 60.7 \\
\hline \multirow{6}{*}{$\begin{array}{l}\text { Number of } \\
\text { children }\end{array}$} & None & 8.1 \\
\hline & 1 child & 28.9 \\
\hline & 2 children & 42.8 \\
\hline & 3 children & 17.3 \\
\hline & 4 children & 2.9 \\
\hline & $>5$ children & \\
\hline
\end{tabular}

Note: $\%=$ Percentage 


\section{Working Mother's Effect on Family Economic Resilience}

Sub-group analysis. Many of the aforementioned studies investigated whether specific sub-groups experience greater harm or decrease in household economic resilience from Covid-19. Sub-group analysis is based on indicators of household resilience and sociodemographic characteristics.

Home Ownership. Families who already have their own house mean that they have been able to fulfill one of their primary needs so that they have the potential to be able to build their families with a better level of family resilience. In other words, families who have occupied their residential buildings are expected to have relatively better economic resilience than families who occupy non-own residential buildings. In this study, about 67 percent or the equivalent of 116 respondents already own a house with details of 63 percent or 74 respondents being their own home and $17 \%$ or the equivalent of 42 respondents having their own house with inheritance status from their parents, so they still live with their parents.

Family Income. Income assessment objectively assumes that families with higher per capita incomes will have better economic resilience. Meanwhile, this subjective income assessment emphasizes more on family satisfaction with the income that has been obtained. This means that families who have a perception that their income is sufficient or more than enough to meet the needs of daily life are expected to have better economic resilience. In this study, respondents or mothers work to maximize potential and education and increase family income. As a result, 75 percent of respondents with full-time employment status have sufficient income and can meet their primary, secondary and tertiary needs.

Children's Education Financing. The presence of family members who have dropped out of school indicates economic problems in the family. In addition to no children dropping out of school, families who have good economic resilience must also be able to guarantee their family members to get an education so that all children can go to school. In this study, none of the respondents experienced dropping out of school during the Covid-19 pandemic. The presence of working mothers helps in providing school fees for children. This study also shows that children of working mothers attend formal schools, but they get facilities such as tutoring.

Family Financial Guarantee. A family is said to have economic resilience if it has financial security in its family. The guarantee can be in the form of savings or investment as well as health insurance. In this study, families with working mothers have higher resilience because they have a surplus of income that can be used to save and buy gold. In addition, they also have health insurance in the form of BPJS first-class, BPJS class 2 and BPJS class 3 , KIS, and personal insurance and insurance from the workplace. In addition, they also have BPJS for employment, have a pension fund, and mandatory savings in the corporation where they work.

Education and Type of Work. Education in a family is positively correlated with the type of work and the amount of income. The level of education significantly affects individual income, where the higher the education level, the income level will also increase (Julianto \& Utari, 2019). In this study, the mother's education average or equal to 11 per cent in high school/equivalent, 45 percent is Bachelor (S1), 25 percent is master (S2). Meanwhile, the type of work in this study was dominated by civil servants, police at 34.7 percent, private employees 27.2 percent, and teachers 15.6 percent. This means that families with working mothers and higher education have a high type of work. Therefore, it has a positive impact on a higher level of family economic resilience.

Age. Age is one of the factors that affect income. The productive age ranges from 15-64 years, which is the ideal age for workers. In the effective period, in general, as people age, income will increase. A person's physical strength to carry out activities is closely related to age. When a person's age has passed the productive period, his physical strength decreases so that productivity decreases and income also decreases. In this study, the age range of working mothers was 98.3 percent were of productive age. This means that working mothers have higher household economic resilience.

Furthermore, Table 2 shows the t-test result of the equation model of working mothers. The $t-$ test is used to test whether an independent variable affects the dependent variable. Based on the output in the table, it is found that working mothers affect household economic resilience. 
Table 2 Summary of regression analysis

\begin{tabular}{lccc}
\hline \multicolumn{1}{c}{ Variabel } & $B$ & $\beta$ & \multicolumn{1}{c}{ Sig. } \\
\hline Constant & 8.244 & & $0.000^{\star *}$ \\
\hline Working mother & 0.400 & \multirow{2}{*}{0.587} & $0.000^{* *}$ \\
$(\mathrm{X})$ & & & 0.344 \\
Adjusted R ${ }^{2}$ & & & 89.176 \\
F & & & $0.000^{\text {** }}$ \\
Sig. & & & \\
\hline
\end{tabular}

Note: $\mathrm{B}=$ unstandardized coefficients, $\beta=$ standardized coefficients; Sig = significance; *significant on $p<0.05$; **significant on $\mathrm{p}<0.01$.

This is because $\mathrm{Ho}$ is rejected, and $\mathrm{Ha}$ is accepted. Therefore, the effect is positive because the $t$ value is positive, meaning that if the mother works, economic resilience also increases.

Table 2 is also the result of the determination coefficient test of the equation model for the effect of working mothers on economic resilience during the pandemic. The coefficient of determination test or the R-Square test serves to see the extent to which the diversity of the dependent variable can be explained or calculated by the variety of the independent variables. Based on the test results above, it can be seen that the R-Square value for the variable of working mothers influences the economic resilience of 34.4 percent. It means that 65.6 percent of influence comes from other factors.

\section{DISCUSSION}

Based on the age, the data shows that respondents aged between 30-39 years are the highest because they are at their productive age and have many necessities in life (Putu Martini Dewi, 2012; Biondi Perdana, 2014). Respondents belong to this age group have started to build their family's economic resilience, such as buying a private house (Rosa, 2016) and preparing for children's education (Dewa Ayu, 2017). Especially during the Covid-19 Pandemic, households are a sector that is prone to experiencing economic shocks (Sina, 2020) as a result of a reduction in income/salary cuts, even layoffs, which reduce and even eliminate income (Mitra, 2020), eventually resulting in an increase in debt in the household economy (Riyadi, 2016). In this case, the type of skilled work referred to is formal and full-time jobs such as professionals, leadership personnel, and executive officers (Panji \& Pitoyo, 2013).

This research shows that working mothers have a positive effect on household economic resilience during Covid-19. This indicates that in the Covid-19 Pandemic, the economic resilience of the family will be more stable if it is influenced by a working mother or wife than if the wife does not work (Wijayanti, 2021). This is in line with research conducted by (Susi Keefe, 2016). The importance of women to work is also evidenced by research in Tanzania, where women play the breadwinner of their families. The growth of the informal sector has increased due to the crisis that hit Tanzania, thus changing the position of Tanzanian women into economic agents and running informal sector businesses. Their works include running a small business selling household needs by using recycled materials (De Haan, Hawley, \& Deal, 2002). This means that situations that threaten the family economy can be overcome by women. Women can be creative and sensitive in facing crises, both at the family and macro levels. So it can be said that the situation around them influences the change in the role of women.

In the end, working mothers have considerable potential to contribute to family income (Dentinger \& Clarkberg, 2002). They may be independent of a husband's income (Brewer \& Gardiner, 2020). They also have creativity, allowing them to develop a high economic value product (Bradley \& Hojjat, 2017). They also still manage to provide children's needs both materially and non-materially (Davies \& Gentile, 2012), improve children's welfare in terms of health (Case, Fertig, \& Paxson, 2004), provide the cost of children's education (ILO, 2017), and increase family economic resilience and save children's future (Paxson \& Schady, 2007). Furthermore, there is a positive relationship between working mothers at the macro level and increased economic development (Hertz et al., 2020).

This research has limitations. The limitation of this study is that it still uses simple analytical techniques. Apart from the factor of the working mother, there are still many factors that can influence the family's economic resilience, such as the husband's income, mother's working hours, mother's income, husband's position, and so on.

\section{CONCLUSION AND SUGGESTION}

This study examines the relationship between the status of working mothers and family economic resilience. Based on the research's results, working mothers affected family economic resilience. The effect was positive, meaning that the family's economic stability would increase as a working mother was 
present and supported the family. This positive influence of family resilience result supports the hypothesis of family resilience is a condition of adequacy and continuity of access to income and resources to meet various basic needs, among others: food, clean water, health services, educational opportunities, housing, time for participation in society, and social integration. In addition, this finding confirms that positive relationship between mother's participation in the labor market on improving the economy, providing higher family resilience, and working mothers become a source of economic and psychological support in times of family difficulties.

In connection with the policy-making based on the results from this research, the government should put more attention on handling and providing the right stimulus in improving the economy, especially during the Covid-19 pandemic. Based on the research results, working mothers influenced household economic resilience during the Covid-19 pandemic. Therefore, the government and related stakeholders are expected to provide working capital for women, the availability of employment opportunities for women, and work regulations that support women in balancing their dual roles. As for future research, it is suggested to include other variables that can affect family resilience during the Covid-19 period.

\section{REFERENCES}

Afifi, T. D., Merrill, A. F., \& Davis, S. (2016). The theory of resilience and relational load. Journal of The International Association For Relationship Research, 23(4), 663-683. doi: https://doi.org/10.1111/pere.12159.

Araújo, L. A. de, Veloso, C. F., Souza, M. de C., Azevedo, J. M. C. de, \& Tarro, G. (2020). The potential impact of the COVID-19 pandemic on child growth and development: a systematic review. Jornal de Pediatria, 23(January), 1-10. doi: 10.1016/j.jped.2020.08.008

Arsal, T., Basri, M., \& Tono, S. (2017). Bakul: Contribution of rural women to family economy through informal sector activities. KOMUNITAS: International Journal of Indonesian Society and Culture, 9(1), 136-142. doi: 10.15294/komunitas.v9i1.8906
Asian Development Bank. (2020). The economic impact of the covid-19 outbreak on developing Asia (ADB Briefs No. 128). doi: 10.22617/BRF200096

Aziz, F. A., \& Sholikha, A. F., \& Ashari, I. (2017). Pengaruh wanita dalam ketahanan ekonomi keluarga studi kasus pada wanita penganyam kerajinan tikar pandan di Desa Pesahangan Cimanggu Cilacap. JPA, 18(2), 241-256. doi: 10.24090/jpa.v18i2.2017.pp241-256

Bagchi-Sen, S. (2010). The small and medium sized exporters' problems: An empirical analysis of canadian the small and medium sized exporters' problems: An empirical analysis of Canadian manufacturers. Regional Studies, 33(3), 231-245.

doi: 10.1080/00343409950082427

Baker, S. R., Farrokhnia, R. A., Meyer, S., Pagel, M., \& Yannelis, C. (2020). How does household spending respond to an epidemic? Consumption during the 2020 Covid-19 pandemic (JEL No. D14, E21, G51 No. No. 26949). The Review of Asset Pricing Studies (Vol. 10). Cambridge. doi: 10.1093/rapstu/raaa009

Bank for International Settlements. (2016). Economic resilience: A financial perspective. Retrieved from https://www.bis.org/publ/othp27.htm

Bhana, A., \& Bachoo, S. (2011). The determinants of family resilience among families in low-and middle-income contexts: a systematic literature review. South African Journal of Psychology, 41(2), 131-139. doi: 10.1177/008124631104100202

[BIS] Bank for International Settlements. (2016). Economic resilience: A financial perspective. Retrieved from https://www.bis.org/publ/othp27.htm.

Bonanno, G. A. (2008). Loss, trauma, and human resilience: Have we underestimated the human capacity to Thrive after extremely aversive events?. American Psychologist, 59(1), 101-113. doi: 10.1037/0003-066X.59.1.20.

Botezat, A., \& Pfeiffer, F. (2014). The impact of parents migration on the well-being of children left behind initial evidence from Romania (14 No. 14-029). Romania, RO: IZA Institute of Labor Economic. https://doi.org/10.2139/ssrn.2432946 
[BPS] Badan Pusat Statistik. (2016). Pembangunan Ketahanan Keluarga. Retrieved from https://www.bps.go.id/news/2015/05/06/11 0/indeks-ketahanan-pangan.html.

[BPS] Badan Pusat Statistik. (2019). Keadaan Angkatan Kerja di Indonesia Februari 2019. Retrieved from https://www.bps.go.id/publication/2019/05/ 31/a96ce41f72e59d5dfb1cad9f/keadaanangkatan-kerja-di-indonesia-februari2019.html.

[BPS] Badan Pusat Statistik. (2020). Angka Putus Sekolah (APTS). Retrieved from https://sirusa.bps.go.id/sirusa/index.php/in dikator/12.

Bradley, J. M., \& Hojjat, M. (2017). A model of resilience and marital satisfaction. Journal of Social Psychology, 157(5), 588-601. doi: 10.1080/00224545.2016.1254592

Brewer, M., \& Gardiner, L. (2020). The initial impact of COVID-19 and policy responses on household incomes. Oxford Review of Economic Policy, 36(S1), S187-S199. doi: 10.1093/oxrep/graa024

Case, A., Fertig, A., \& Paxson, C. (2004). The lasting impact of childhood health and circumstance. Journal of Health Economics, 24(2), 365-389. doi: 10.1016/j.jhealeco.2004.09.008

Casmini. (2020). Read the reality of family resilience in facing pandemics Covid-19 in Indonesia. International Journal of Psychosocial Rehabilitation, 24(10), 4354-4365. Retrieved from http://digilib.uinsuka.ac.id/id/eprint/40395/.

Celik, B., Ozden, K., \& Dane, S. (2020). The Effects of COVID-19 Pandemic on Surgery of Cancer Patients. Journal of Research in Medical and Dental Science, 8(4), 51-56. Available Online at: www.jrmds.in elSSN No. 2347-2367: pISSN No. 2347-2545.

Cross, E. R., \& Emanuel, L. (2008). Providing Inbuilt economic resilience options an obligation of comprehensive cancer care. Cancer, 113(12 SUPPL.), 3548-3555. doi: $10.1002 /$ cncr.23943

Davies, J. J., \& Gentile, D. A. (2012). Responses to children's media use in families with and without siblings: A family development perspective. Family Relations, 61(3), 410-425. doi: 10.1111/j.1741-3729.2012.00703.x
De Haan, L., Hawley, D. R., \& Deal, J. E. (2002). Operationalizing family resilience: A methodological strategy. American Journal of Family Therapy, 30(4), 275291. doi: $10.1080 / 01926180290033439$

Dentinger, E., \& Clarkberg, M. (2002). Informal caregiving and retirement timing among men and women: gender and caregiving relationships in late midlife. Journal of Family Issues, 23(7), 857-879. doi: $10.1177 / 019251302236598$

Dewi, P. M. (2012). Pastisipasi tenaga kerja perempuan dalam meningkatkan pendapatan keluarga. Jurnal Ekonomi Kuantitatif Terapan, 5(2), 119-124. Retrieved from https://ojs.unud.ac.id/index.php/jekt/article/ view/1906

Dhingra, V., \& Keswani, S. (2018). Impact of working mothers on their children's development. Inovation The Research Concept, 3(3), 18-25. doi: 10.32622/jirat.732019104

Donnelly, K., Twenge, J. M., Clark, M. A., Shaikh, S. K., Beiler-May, A., \& Carter, N. T. (2016). Attitudes toward women's work and family roles in the United States, 1976-2013. Psychology of Women Quarterly, 40(1), 41-54. doi: $10.1177 / 0361684315590774$

Duflo, E. (2012). Women empowerment and economic development. Journal of Economic Literature, 50(4), 1051-1079. doi: 10.1257/jel.50.4.1051

Faccio, F., Renzi, C., Giudice, A. V, Pravettoni, G., Tumori, I., \& Paolo, G. (2018). Family resilience in the oncology setting: development of an integrative framework. Frontiers in Psychology, 9(3), 1-6. doi: 10.3389/fpsyg.2018.00666

Fallah, B., Bergolo, M., Hashhash, A. A., Hattawy, M., \& Saadeh, I. (2019). The effect of labor-demand shocks on women's participation in the labor force: Evidence from Palestine. United Kingdom. doi: 10.2139/ssrn.3410521

Feinberg, L., Reinhard, S. C., Houser, A., \& Choula, R. (2011). Valuing the invaluable: 2011 update the growing contributions and costs of family caregiving. AARP Public Policy Institute. Retrieved from http://assets.aarp.org/rgcenter/ppi/ltc/i51caregiving.pdf.

Ghazi, S. R., Ali, R., Shahzad, S., Shahzada, G., \& Nawaz, K. (2011). Socio-economic factors as a cause of children dropout at 
primary level. Mediterranean Journal of Social Sciences, 2(3), 531-536. doi: 10.5901/mjssv2n3p531.

Ghozali, I. (2013). Aplikasi analisis multivariate dengan program IBM SPSS 21 update PLS regresi (7th ed.). Semarang, ID: Badan Penerbit Universitas Diponegoro.

Ginanjar, A. S., Primasari, I., Rahmadini, R., \& Astuti, R. W. (2020). Hubungan antara work-family conflict dan work-family balance dengan kepuasan pernikahan pada istri yang menjalani dual-earner family. Jurnal IImu Keluarga dan Konsumen, 13(2), 112-124. doi: 10.24156/jikk.2020.13.2.112

Hertz, R., Mattes, J., \& Shook, A. (2020). When paid work invades the family: Single mothers in the covid-19 pandemic. Journal of Family Issues, 00(0), 1-27. doi: 10.1177/0192513X20961420

Hoque, M. M., Khanam, S. T., \& Nobi, M. N. (2017). The effects of mothers ' profession on their children ' $s$ academic performance: an econometric. Global Journal of HUman-Social Science: Economics, 17(2), 1-10. Retrieved from https://globaljournals.org/GJHSS_Volume 17/1-The-Effects-of-Mothers-Profession

Hosna, A. U., Wahab, S. A., Hamid, M., Hasanat, M. W., Haque, A., Anum, K., \& Kamruzzaman, M. (2020). Impact of mental pressure and coronavirus (Covid19) on the work performance of working mothers of Bangladesh. American International Journal of Business Management (AlJBM), 3(12), 63-69. Retrieved from https://www.aijbm.com/wpcontent/uploads/2020/12/K3126369.pdf

Huebener, M., Waights, S., Spiess, C. K., Siegel, N. A., \& Wagner, G. G. (2021). Parental well-being in times of Covid-19 in Germany. Review of Economics of the Household, 19(1), 91122. doi: 10.1007/s11150-020-09529-4

ILO \& Gallup. (2017). Towards a better future for women and work: Voices of women and men. https://www.ilo.org/wcmsp5/groups/public/ ---dgreports/---dcomm/publ/documents/publication/wcms_546256 .pdf

Solihatin, I. R. (2017). Konsepsi Al-Qur'an tentang perempuan pekerja dalam mensejahterakan keluarga. Jurnal Harkat:
Media Komunikasi Gender, 12(2), 78-91. doi: 10.15408/harkat.v13i1.7714

Julianto, D., \& Utari, P. A. (2019). Analisa pengaruh tingkat pendidikan terhadap pendapatan individu di sumatera barat. Ikraith Ekonomika, 2(2), 122-131. https://journals.upi-yai.ac.id/index.php/ IKRAITH-EKONOMIKA/article/view/413

Kansiime, M. K., Tambo, J. A., Mugambi, I., Bundi, M., Kara, A., \& Owuor, C. (2021). COVID-19 implications on household income and food security in Kenya and Uganda: Findings from a rapid assessment. World Development, 137, 105199.

doi:

10.1016/j.worlddev.2020.105199

Karpman, M., Gonzalez, D., \& Kenney, G. M. (2020). Parents are struggling to provide for their families during the pandemic. The Urban Institute. Retrieved from https://www.urban.org/sites/default/files/pu blication/102254/parents-are-struggling-toprovide-for-their-families-during-thepandemic_1.pdf.

Keefe, S. (2016). Women, work, and (re)marriage: Entrepreneurship among swahili women in Coastal Tanzania. Africa Today, 62(3), 111-131. Retrieved from https://muse.jhu.edu/article/610773/pdf.

[Kemendikbud] Kementerian Pendidikan, Kebudayaan, Riset, dan Teknologi Republik Indonesia. (2020). Statistik Pendidikan. Retrieved from http://statistik.data.kemdikbud.go.id/.

Krejcie, R. V, \& Morgan, D. W. (1970). Determining sample size for research activities. Educational and Psychological Measurment, 30, 607-610.

Kring, S. A. (2017). Gender in employment policies and programmes: What works for women employment? Working Paper No. $235 . \quad$ Retrieved from https://www.ilo.org/employment/Whatwed o/Publications/working-papers/WCMS 613536/lang--en/index.htm

Lei, L., Liu, F., \& Hill, E. (2017). Labour migration and health of left-behind children in China. Journal of Development Studies, 54(1), 1-18. doi: 10.1080/00220388.2017.1283015.

[LIPI]. Lembaga IImu Pengetahuan Indonesia. (2020). Dampak pandemi Covid-19 terhadap ketahanan pangan rumah tangga. Jakarta, ID: LIPI. Retrieved from 
https://ekonomi.lipi.go.id/public/images/pu blikasi/1619602983_Strategi_Kebijakan_P enanganan_Dampak.pdf

Lobo., K. B. \& M. (2008). A conceptual review of family resilience factors. Journal of Family Nursing, 14(1), 33-55. doi: $10.1177 / 1074840707312237$.

Martin, A., Markhvida, M., Hallegatte, S., \& Walsh, B. (2020). Socio-economic impacts of COVID-19 on household consumption and poverty. Economics of Disasters and Climate Change, 4(4), 453-479. doi: 10.1007/s41885-020-00070-3

Masten, A. S. (2018). Resilience theory and research on children and families: Past, present, and promise. Journal of Family Theory and Review, 10(1), 12-31. doi: 10.1111/jtr.12255

Melis, M. (2017). Relevansi peran gender dan kontribusi ekonomi perempuan untuk mencapai falah dalam rumah tangga. An Nisa'a, 12(1), 65-76. Retrieved from http://jurnal.radenfatah.ac.id/index.php/an nisa/article/view/1506

Mitra, R. S. (2020). Household finance during the covid-19 pandemic. https://www.researchgate.net/publication/3 42003888_Household_Finance_During_th e_COVID-19_Pandemic

Moen, P., \& Yu, Y. (2000). Effective work/life strategies: Working couples, work conditions, gender, and life quality. Social Problems, 47(3), 291-326. https://doi.org/10.2307/3097233

Munandar, A. I., \& Suryatman, A. (2019). Family resilience index in student: case study vocational high school in Bekasi. In Proceedings of the 2nd International Conference on Education, Purwokerto. Retrieved from https://eudl.eu/pdf/10.4108/eai.28-92019.2290988

Muttaqin, T., Wittek, R., Heyse, L., \& Van Duijn, M. (2017). Why do children stay out of school in indonesia?. Jurnal Perencanaan Pembangunan: The Indonesian Journal of Development Planning, 1(2), 93-108. doi: 10.36574/jpp.v1i2.12

Muykim, C. (2020). COVID-19: Socioeconomic impacts. Cambodia Development Center, 2(3, 04 April), 1-19. Retrieved from https://cd-center.org/wpcontent/uploads/2020/04/P124_20200404 _V2IS3.pdf
Paxson, C., \& Schady, N. (2007). Cognitive development among young children in Ecuador: The roles of wealth, health, and parenting. Journal of Human Resources, 42(1), 49-84. doi: 10.2139/ssrn.753548

Perdana, B. (2014). Partisipasi kerja perempuan dalam meningkatkan kesejahteraan keluarga (studi kasus pada KUD Sumber Makmur Kecamatan Ngantang Kabupaten Malang 2013). Jurnal Ilmiah Mahasaiwa FEB, 2(2). Retrieved from https://jimfeb.ub.ac.id/index.php/jimfeb/arti cle/view/1329

Prayogo, C. (Ed.). (2020, October 19). Dampak pandemi Covid-19 terhadap perekonomian dunia. Warta Ekonomi. Retrieved from www.wartaekonomi.co.id/read309848/da mpak-pandemi-covid-19-terhadapperekonomian-dunia-infografis.

Rani, I. D. A. P. W., \& Aswitari, L. P. (2017). Analisis determinan pendapatan perempuan pedagang cenderamata di pasar seni Desa Adat Kuta Kabupaten Badung. E-Jurnal Ekonomi Pembangunan Unud, 8(5), 1033-1061. Retrieved from https://ojs.unud.ac.id/index.php/eep/article /view/43685.

Rangvid, B. S. (2008) School composition effects in Denmark: Quantile regression evidence from PISA 2000. In Dustmann C., Fitzenberger B., Machin S. (eds) The Economics of Education and Training. Studies in Empirical Economics. Heidelberg: Physica-Verlag. doi: 10.1007/978-3-7908-2022-5_9.

Riyadi, S. (2016). Analisis Faktor-faktor yang mempengaruhi tingkat partisipasi angkatan kerja wanita Daerah Tingkat 1 Jawa Timur. Ekuitas: Jurnal Ekonomi Dan Keuangan, 5(1), 32. https://doi.org/http://dx.doi.org/10.24034/j2 5485024.y2001.v5.i1.1920.

Rosa, Y. (2016). Kebutuhan tipe hunian berdasarkan umur dan status kepala keluarga. Jurnal Pemukiman, 11(2), 8899. Retrieved from http://jurnalpermukiman.pu.go.id/index.ph $\mathrm{p} / \mathrm{JP} /$ article/view/6

Saleh, A. S., \& Ndubisi, N. O. (2014). An evaluation of SME development in Malaysia. International Review of Business Research Papers V, 02(1), 114. Retrieved from https://www.researchgate.net/publication/2 
28869311_An_evaluation_of_SME_devel opment_in_Malaysia.

Sawada, Y., \& Sumulong, L. R. (2021). Macroeconomic impact of COVID-19 in developing Asia (No. 1251). Tokyo. Retrieved from https://www.adb.org/publications/macroec onomic-impact-covid-19-developingasia\%0D.

Sekaran, U. (2003). Research methods for business: $A$ skill building aproach (4th ed.). New York, US: John Wiley and Sons, Inc.

Setiawan, T., Kasim, S., \& Yusuf, B. (2020). Eksistensi pekerja perempuan (istri) pada sektor informal dalam meningkatkan kesejahteraan keluarga: Studi Kelurahan Abeli Kecamatan Abeli Kota Kendari. Well-Being: Journal of Social Welfare, 1(1), 110-116. Retrieved from http://ojs.uho.ac.id/index.php/wellbeing/arti cle/view/16530

Shahreza, D., \& Lindiawatie. (2020). Ketahanan ekonomi keluarga di Depok pada masa pandemi Covid-19. Journal of Applied Business and Economics (JABE), $7(2)$, 148-161. Retrieved from https://journal.lppmunindra.ac.id/index.php /JABE/article/view/7487

Simon, M. A., Gunia, B., Martin, E. J., Foucar, C. E., Kundu, T., Ragas, D. M., \& Emanuel, L. L. (2013). Path toward economic resilience for family caregivers: Mitigating household deprivation and the health care talent shortage at the same time. Gerontologist, 53(5), 861-873. doi: 10.1093/geront/gnt033

Sina, P. G. (2020). Ekonomi rumah tangga di era pandemi covid-19. Journal of management (SME's), 12(2), 239-254. doi: 10.35508/jom.v12i2.269

Sinval, J., Sirgy, M. J., Lee, D. J., \& Marôco, J. (2020). The quality of work life scale: validity evidence from brazil and portugal. Applied research in quality of life, 15(5), 1323-1351. https://doi.org/10.1007/ s11482-019-09730-3

Stephiana, O., \& Wisana, I. D. G. K. (2019). The mother's role in child development: the effect of maternal employment on cognitive development. Pertanika Journal of Social Sciences and Humanities, 27(4), 2571-2583. Retrieved from https://www.researchgate.net/profile/l-
Dewa-Gede-Karma-

Wisana/publication/334748851.

Sunarti, E. (2006). Indikator keluarga sejahtera: Sejarah pengembangan, evaluasi, dan keberlanjutannya. Retrieved from https://repository.ipb.ac.id/jspui/handle/12 3456789/54504

Sunarti, E., Rizkillah, R., Hakim, F. A., Zakiya, N., \& Damayanti, R. (2021). Manajemen sumber daya keluarga, konflik kerjakeluarga, dan tugas keluarga. Jurnal IImu Keluarga dan Konsumen, 14(1), 1-13. doi: 10.24156/jikk.202 1.1 4.1.1

Supriatna, E. (2020). Socio-economic impacts of the covid-19 pandemic: The case of Bandung City. Journal of Governance, 5(1), 61-70. doi: 10.31506/jog.v5i1.8041

Suryahadi, A., Izzati, R. A., \& Suryadarma, D. (2020). Estimating the Impact of COVID19 Outbreak on Poverty. Bulletin of Indonesian Economic Studies, 1-33. doi: 10.1080/00074918.2020.1779390

Suryono, P., \& Pitoyo, A. J. (2013). Kesesuaian tingkat pendidikan dan jenis pekerjaan pekerja di Pulau Jawa: Analisis data Sakernas tahun 2010. Jurnal Bumi Indonesia, 2(1), 59-68. Retreived from http://lib.geo.ugm.ac.id/ojs/index.php/jbi/ar ticle/view/127

Susilawati, Falefi, R., \& Purwoko, A. (2020). Impact of covid-19's pandemic on the economy of Indonesia. Budapest International Research and Critics Institute (BIRCl-Journal): Humanities and Social Sciences, 3(2), 1147-1156. doi: 10.33258/birci.v3i2.954.

Susi Keefe. (2016). Women, Work, and $(\mathrm{Re})$ Marriage: Entrepreneurship among Swahili Women in Coastal Tanzania. Africa Today, 62(3), 111-131.

[UNCTAD] United Nations Conference On Trade And Development. (2020). The Covid-19 Shock to Developing Countries: Towards a " whatever it takes" programme for the two-thirds. Retrieved from https://unctad.org/system/files /official-document/gds_tdr2019_covid2 _en.pdf

Verma, A., \& Negi, Y. S. (2020). Working women and motherhood - a review. Annals of Agri Bio Research, 25(1), 170178. Retrieved from http://agribiop.com/working-women-andmotherhood-a-review/ 
Weinstein, M. C. (1996). Recommendations of the panel on cost-effectiveness in health and medicine. JAMA: The Journal of the American Medical Association, 276(15), 1253. doi: 10.1001/jama.1996.03540150055

Wijayanti, U. T. (2021). Analisis faktor penyebab perceraian pada masa pandemi covid-19 di Kabupaten Banyumas. Jurnal IImu Keluarga \& Konsumen, 14(1), 14-26. doi: 10.24156/jikk.2021.14.1.14

Wulandari, A., Putri, A. K., \& Yulia. (2019). Women working hours as a family economic stabilization: Study on pepper farmers in dellas village, air gegas sub disrtric, South Bangka Regency. In International Conference on Maritime and
Archipelago (ICoMA 2018) Women (pp. 277-280). Atlantis Press. doi: 10.2991/icoma-18.2019.59

Yue, P., Gizem Korkmaz, A., \& Zhou, H. (2020). Household financial decision making amidst the covid-19 pandemic. Emerging Markets Finance and Trade, 56(10), 2363-2377. doi: 10.1080/1540496x.2020.1784717

Yulianti, K., Denessen, E., \& Droop, M. (2019). Indonesian parents' involvement in their children's education: A study in elementary schools in urban and rural Java, Indonesia. School Community Journal, 29(1), 253$278 . \quad$ Retrieved from https://www.adi.org/journal/2019ss/Yulianti SS2019.pdf 